\title{
Pituitary hormone receptors and tumorigenesis
}

\author{
Anat Ben-Shlomo and Shlomo Melmed \\ Department of Medicine, Cedars Sinai Medical Center, UCLA School of Medicine, Los \\ Angeles, California, USA. Correspondence to S.M.e-mail: Melmed@csmc.edu
}

We read with interest the Review 'G-protein-coupled receptors and cancer' by Dorsam and Gutkind published in Nature Reviews Cancer'. In table 1 the authors state inaccurately that thyrotropin secreting hormone (TSH) and adrenocorticotropin hormone (ACTH) receptors (TSHR and ACTHR, respectively) cause pituitary tumours.

The pituitary gland secretes six polypeptide hormones - ACTH, TSH, growth hormone $(\mathrm{GH})$, gonadotropins (follicle stimulating hormone (FSH) and luteinizing hormone (LH)) and prolactin. These trophic hormones act at their respective target glands (adrenals, thyroid, cartilage, gonads and breast) to regulate peripheral hormone secretion and glandular growth and differentiation ${ }^{2}$.

TSH is secreted by the pituitary and signals through the TSHR at the thyroid gland to induce thyroid hormone synthesis. Several naturally occurring mutations are found in the TSHR ${ }^{3-5}$. Activating, somatic TSHR mutations cause toxic thyroid adenomas ${ }^{6}$, and activating, germline TSHR mutations can cause hereditary toxic thyroid hyperplasia ${ }^{7}$ and familial gestational hyperthyroiditis ${ }^{8}$. Inactivating, germline TSHR mutations can cause partial or complete resistance to $\mathrm{TSH}^{9,10}$ or isolated central hypothyroidism ${ }^{11}$. No TSHR mutation is yet known to cause pituitary tumours; moreover, TSHR mutations are unlikely do so, as TSH is secreted by the pituitary and acts at the periphery.

ACTH is secreted by the pituitary gland and acts peripherally at the ACTHR (currently known as melanocortin 2 receptor $\left(\mathrm{MC}^{2} \mathrm{R}^{3}\right)$ ) in the adrenal glands to induce adrenal steroid synthesis. An inactivating, germline mutation in MC2R was shown to cause familial glucocorticoid deficiency in $25 \%$ of patients with this disease ${ }^{12}$. A deletion of MC2R was found in two very aggressive undifferentiated adrenocortical tumours ${ }^{13}$. Adrenal tumours have not been found to harbour gain-of-function mutations of $M C 2 \mathrm{R}^{3,14,15}$. No MC2R mutation is known to cause pituitary tumours.

1. Dorsam, R. T. \& Gutkind, J. S. G-protein-coupled receptors and cancer. Nature Rev. Cancer 7, 79-94 (2007).

2. Melmed, S. Mechanisms for pituitary tumorigenesis: the plastic pituitary. J. Clin. Invest. 112, 1603-1618 (2003).

3. Lania, A. G., Mantovani, G. \& Spada, A. Mechanisms of disease: mutations of G proteins and G-protein-coupled receptors in endocrine diseases. Nature Clin. Pract. Endocrinol. Metab. 2, 681-693 (2006).

4. Davies, T. F., Ando, T., Lin, R. Y., Tomer, Y. \& Latif, R. Thyrotropin receptorassociated diseases: from adenomata to Graves disease. J. Clin. Invest. $1 \mathbf{1 5}$ 1972-1983 (2005).

5. Krohn, K. et al. Molecular pathogenesis of euthyroid and toxic multinodular goiter. Endocr. Rev. 26, 504-524 (2005).

6. Parma, J. et al. Somatic mutations in the thyrotropin receptor gene cause hyperfunctioning thyroid adenomas. Nature 365, 649-651 (1993).

7. Fuhrer, D., Wonerow, P., Willgerodt, H. \& Paschke, R. Identification of a new thyrotropin receptor germline mutation (Leu629Phe) in a family with neonatal onset of autosomal dominant nonautoimmune hyperthyroidism. J. Clin.

Endocrinol. Metab. 82, 4234-4238 (1997).

8. Rodien, P. et al. Familial gestational hyperthyroidism caused by a mutant thyrotropin receptor hypersensitive to human chorionic gonadotropin. N. Engl. J. Med. 339, 1823-1826 (1998).

9. Abramowicz, M. J., Duprez, L., Parma, J., Vassart, G. \& Heinrichs, C. Familial congenital hypothyroidism due to inactivating mutation of the thyrotropin 
receptor causing profound hypoplasia of the thyroid gland. J. Clin. Invest. 99 , 3018-3024 (1997).

10.Sunthornthepvarakui, T., Gottschalk, M. E., Hayashi, Y. \& Refetoff, S. Brief report: resistance to thyrotropin caused by mutations in the thyrotropin-receptor gene. N. Engl. J. Med. 332, 155-160 (1995).

11.Collu, R. et al. A novel mechanism for isolated central hypothyroidism: inactivating mutations in the thyrotropin-releasing hormone receptor gene. J. Clin. Endocrinol. Metab. 82, 1561-1565 (1997).

12.Clark, A. J., McLoughlin, L. \& Grossman, A. Familial glucocorticoid deficiency associated with point mutation in the adrenocorticotropin receptor. Lancet $\mathbf{3 4 1}$, 461-462 (1993).

13. Reincke, M. et al. Deletion of the adrenocorticotropin receptor gene in human adrenocortical tumors: implications for tumorigenesis. J. Clin. Endocrinol. Metab. 82, 3054-3058 (1997).

14. Reincke, M. Mutations in adrenocortical tumors. Horm. Metab. Res. 30 , 447-455 (1998).

15. Beuschlein, F., Fassnacht, M., Klink, A., Allolio, B. \& Reincke, M. ACTHreceptor expression, regulation and role in adrenocortial tumor formation. Eur. J. Endocrinol. 144, 199-206 (2001). 